\title{
INQUIRY-DISCOVERY EMPOWERING HIGH ORDER THINKING SKILLS AND SCIENTIFIC LITERACY ON SUBSTANCE PRESSURE TOPIC
}

\author{
Wartono $^{1}$, Johannis Takaria ${ }^{2}$, John Rafafy Batlolona*³, Sascha Grusche ${ }^{4}$, \\ Muhammad Nur Hudha ${ }^{5}$, Y. M. Jayanti ${ }^{6}$ \\ ${ }^{1}$ Department of Physics, Faculty of Mathematics and Natural Sciences, State University of Malang, Indonesia \\ ${ }^{2,3}$ Primary School Teacher Education Study Program, Teaching and Education Faculty, Pattimura University, Indonesia \\ ${ }^{4}$ Physics Education, Pädagogische Hochschule Weingarten, Kirchplatz 2, 88250 Weingarten, Germany \\ $5,{ }^{6}$ Physics Education Study Program, Faculty of Science and Technology, Universitas Kanjuruhan Malang, Indonesia \\ *corresponding author: johanbatlolona@gmail.com; john_batlolona@yahoo.co.id
}

Received: July $1^{\text {st }}, 2018$. Accepted: October $21^{\text {st }}$, 2018. Published: October $28^{\text {th }}, 2018$

\begin{abstract}
Inquiry-discovery learning plays an important role in improving high-order thinking skills (HOTS) and scientific literacy (SL). In this HOTS and SL research, it was designed with Inquiry-discovery based learning. The purpose of this study was to promote Inquiry discovery models in empowering higherorder thinking skills and scientific literacy in physics with different classes. This research used QuasiExperimental Design research, and Pretest-Posttest Control Group Design. The research analysis design matrix used two-way ANOVA. The sample was taken from two classes, namely the experimental and control classes of 68 students. The results of the study prove that Inquiry discovery can improve HOTS and SL physics of students. Thus, inquiry-discovery can be recommended to increase student's HOTS and SL physics when compared to conventional classes. The novelty of this study is that inquiry-discovery learning models are more likely to reconstruct students' scientific knowledge of physics on aspects of HOTS and SL with real-world life.
\end{abstract}

(C) 2018 Physics Education, UIN Raden Intan, Lampung, Indonesia.

Keywords: HOTS, initial ability, inquiry-discovery, scientific literacy, substance pressure

\section{INTRODUCTION}

One component that must be developed in learning today is high-order thinking skills (Madhuri, Kantamreddi, \& Prakash Goteti, 2012; Polly, Ausband, Polly, \& Ausband, 2014). The HOTS concept originated from Bloom's taxonomy of cognitive domains introduced in 1956 (Forehand, 2011). The cognitive domain involves knowledge and development of intellectual skills (Bloom, 1956). This includes withdrawal or recognition of specific facts, procedural patterns, and concepts that function to develop intellectual abilities and skills. There are six main categories of cognitive processes, starting from the simplest to the most complex. Bloom categorizes intellectual behavior into six levels of thought: knowledge, understanding, application, analysis, synthesis, and evaluation (Clark, 2010; Yahya, Toukal, \& Osman, 2012).

HOTS is a thought process that involves mental activities in an effort to explore complex, reflective and creative experiences that are carried out consciously to achieve learning goals, namely gaining knowledge that includes the level of analytical thinking, synthesis, evaluative and producing many productive solutions (Miri, David, \& Uri, 2007). HOTS consists of analysis, evaluation, synthesis, developing skills in problem solving, concluding, estimating, predicting, generalizing and creative thinking (Wilks, 1995), while other aspects are asking questions, decision making, critical and systematic thinking (Dillon \& Scott, 2002; Zohar, 2004; Zoller, Dori, \& Lubezky, 2002). HOTS can be seen from the achievements reached by each student, including the 
results of the state and private junior high school national exams in Indonesia. In 2016, the average scores of 890 schools were 65.05. In 2017, the average scores of 8,882 schools that used Computer-Based National Examination were 55.51 while the average scores of 17,760 schools are 52,96 in 2018 (Putri, 2018). This fact proves that Indonesian student achievement has declined. Thus, the teacher as the main trainer of learning is required to be able to facilitate students in thinking in each learning process (W. Wartono, Diantoro, \& Bartlolona, 2018; Wartono Wartono, Hudha, \& Batlolona, 2018). One aspect that facilitates students to think high is experiment-based learning that is shown in Figure 1.

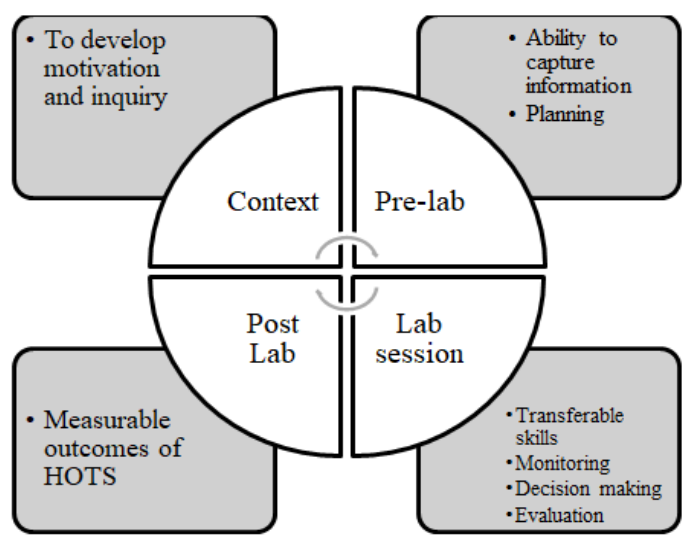

Figure 1. Experimental workflow with HOTS (Madhuri et al., 2012)

In addition to the abilities that must be possessed by each student, another aspect that can be empowered is scientific literacy. SL is defined as the ability to use scientific knowledge, identify questions, draw conclusions based on available evidence, and understand and make decisions regarding nature and changes made to nature through human activities (Firman, 2007; PISA 2006 Programme for International Student Assessment, 2006). SL ability is defined as a person's ability to distinguish scientific facts from various information, recognize and analyze the use of scientific inquiry methods and the ability to organize, analyze, and interpret quantitative data and scientific information (Gormally, Brickman, \& Lut, 2012). SL can also be defined as the basic knowledge and skills needed by an individual to participate in the scientific process (Turgut, 2007). The concepts of mathematical literacy, computer literacy, biological literacy, chemical literacy, communication literacy and statistical literacy that all appear after the definition of scientific literacy (Çepni, S., Ayvacı, H. Ş., \& Bacanak, 2004).

The 2000 and 2003 PISA results divide the SL aspects into three important domains, among others, science content, science processes, and science application contexts (OECD, 2001, 2004) while the 2006 and 2009 PISA developed SL into four major domains including science content, scientific competence/process, science applications, and attitudes. Domain attitudes in PISA 2006 and 2009, more supportive of scientific inquiry, confidence, interest in science and a sense of responsibility for resources and the environment (OECD, 2006). In PISA 2009 the definition of SL was the same as in PISA 2006, and divided SL into four domains as in PISA 2006, except that the difference is attitude domains were not included in the test items in PISA 2009 (OECD, 2009); while PISA 2015 emphasizes science, reading and mathematical skills (OECD, 2014).

SL is important to be mastered by students in relation to the way students can understand the environment, health, economy, politics and other problems faced by a modern society that is highly dependent on ICT, as well as the development of science (Yuenyong, 2013). One of the efforts to increase SL in physics learning is by fostering understanding of concepts. Increasing HOTS and SL in each student depends on their initial abilities (Fives, Huebner, Birnbaum, \& Nicolich, 2014; W. Wartono et al., 2018).

Initial ability is a prerequisite that students must have before entering the 
next higher learning. A student who has the good initial ability will more quickly understand the learning material so that it has an effect on learning outcomes. In contrast to students who have initially weak knowledge will adversely affect their learning outcomes (Piten, Rakkapao, \& Prasitpong, 2017). Therefore, students must have the initial ability before starting learning so that they can participate in learning activities well.

It must be noted that the initial ability will affect a student in receiving new knowledge. Therefore, if the initial knowledge of students is low it will affect the next learning (Jonassen, 1991) so that it will affect their ability to think highlevel and scientific literacy. Therefore, in the learning process, teachers should choose models that can grow HOTS and SL students and in accordance with the objectives to be achieved in learning activities. The learning model that is used must be able to involve students and find their own constructive new concepts. One learning model that involves and trains students to learn to find is inquirydiscovery learning.

Inquiry-discovery learning is a combination of two learning models namely the inquiry model and discovery model. An inquiry is an extension of the discovery process that is used more deeper meaning that the inquiry process contains higher-level mental processes to obtain and obtain information by conducting observations or experiments (Sund, R. B., \& Trowbridge, 1973). An inquiry is more directed to the process of investigation, excavation, finding the latest things, and reviewing objects that must be studied (Meijerman, Storm, Moret, \& Koster, 2013), while discovery prioritizes reflection, thinking, experimenting, and exploring (Bruner, 1961). Discovery is a learning model that finds concepts through a series of data or information obtained through observation or experiment and provides opportunities for students to find themselves without the help of teachers (Saab, Van Joolingen, \& Van Hout-Wolters, 2005). Learning with discovery can encourage students to learn through active involvement or experience by experimenting to discover their own concepts and principles (In'am, Akhsanul; Hajar, 2017).

Inquiry-discovery learning is learning that allows students to use all their potentials both cognitive, effective, and psychomotor, especially mental processes to discover their own concepts or principles of physics and can train other mental processes that characterize a scientist (Klahr \& Nigam, 2004). By inquiry-discovery learning, the discovery of knowledge by means of observation, experimentation, and problem-solving can be achieved, the knowledge gained by students will be more meaningful because, in this learning, students themselves are looking for and discovering their knowledge (Tompo, Ahmad, \& Muris, 2016).

The use of inquiry-discovery learning is very relevant to the steps of the scientific method, and learning theories such as Piaget's cognitive theory, conditioning and constructive (Richardson \& Renner, 1970).

Investigation and discovery of concepts need to be trained in students in learning activities so that students are accustomed to independent learning and able to understand the material being studied. Physics material at junior high and high school level is still considered difficult by students (Batlolona, J. R. \& Haumahu., 2016). One of the physics materials at junior high school is the pressure and its application in everyday life. The pressure material on liquid and its application in daily life is abstract material, so students find it difficult to understand the concepts being taught (Loverude, Kautz, \& Heron, 2003; Susman \& Pavlin, n.d.). Learning in this material is very necessary to be visualized 
so that students can see clearly about the phenomenon that exists. Visualization of the phenomenon can make students really understand the concept as a whole (Taale, 2011). Based on the problems described above, the aim of this research is to promote Inquiry-discovery learning models in empowering higher-order thinking skills and scientific literacy in physics with different classes.

\section{METHOD}

\section{Research Background}

This study used a type of QuasiExperimental Design research and Pretest-Posttest Control Group Design. The research analysis design matrix used two-way ANOVA.

\section{Population and Research Sample}

The population in this study were all eighth-grade students of public junior high school 10 in Malang city. This study used two classes as samples, namely VIII $\mathrm{C}$ class as the experimental class and VIII $\mathrm{B}$ as the control class, where the sampling technique used is cluster random sampling. The sample selection was determined by looking at the students' initial abilities as seen from the results of the formative tests.

The measurement instrument to measure HOTS and SL in this study used a description test form, which was arranged based on indicators in these variables, while the initial ability was taken from the previous formative test scores. Before the instrument was used, it was tested to meet the requirements of validity and reliability with a value of 0.7 and 0.8 .

The data in this study were collected through the test and non-test instruments, which means both quantitative and qualitative. Quantitative data were collected through written tests namely pretest and posttest. Qualitative data were collected through interviews of the initial and final test results. The learning process uses inquiry-discovery learning developed.

The results of HOTS and SL were then tested to find out the improvement achieved by students in that ability. The Improvement of high-order thinking skills and scientific literacy can be known by performing the $\mathrm{N}$-Gain test.

\section{Data analysis}

The analysis technique used in this study is quantitative and qualitative data analysis techniques. Qualitative data analysis techniques are by conducting interviews. The two types of quantitative data analysis techniques used are prerequisite tests and hypothesis testing using SPSS 16.0 for Windows. The two types of prerequisite tests are the normality test and homogeneity test. The normality test uses a One-Sample Kolmogorov-Smirnov Test and homogeneity test using the Test of Homogeneity of Variances, while the hypothesis test uses a two-way ANOVA test (Two-Way ANOVA). Criteria for testing hypotheses $(\alpha=0.05)$, namely if sig $>0.05$ then $\mathrm{H}_{0}=$ accepted, $\mathrm{H}_{1}=$ rejected and if sig $<0.05$ then $\mathrm{H}_{0}=$ rejected, $\mathrm{H}_{1}=$ accepted.

\section{RESULTS AND DISCUSSION Student Initial Capacity Value Data}

Description of students' initial ability data for the experimental class and control class is presented in Table 1.

Table 1. Initial Students' Ability

\begin{tabular}{ccc}
\hline Learning & $\begin{array}{c}\text { Number of } \\
\text { Samples }\end{array}$ & Average \\
\hline Inquiry-discovery & 34 & 67,40 \\
\hline Conventional & 34 & 67,43 \\
\hline
\end{tabular}

Based on Table 1, it can be seen, that the average value of the initial ability of the experimental class students is 67.40 , while the control class has an average value of 67.43. Based on these results, the difference in the average value of the initial ability of students between the 
experimental class and the control class is 0.03 . Table 1 shows the data of students' initial ability scores between the experimental class and the control class is evenly distributed. Furthermore, the description of HOTS data and student SL is shown in Tables 2 and 3.

Table 2. Student HOTS Value Data

\begin{tabular}{cccc}
\hline Class & $\begin{array}{c}\text { Type of } \\
\text { Test }\end{array}$ & $\begin{array}{c}\text { The number } \\
\text { of students }\end{array}$ & Average \\
& & & 48,63 \\
Experiment & Pretest & 34 & 78,97 \\
& & & 44,71 \\
Control & Posttest & 34 & 71,97 \\
\hline
\end{tabular}

Table 3. Student SL Value Data

\begin{tabular}{cccc}
\hline Class & $\begin{array}{c}\text { Type of } \\
\text { Test }\end{array}$ & $\begin{array}{c}\text { The number } \\
\text { of students }\end{array}$ & Average \\
\hline & & & 54,53 \\
Experiment & Pretest & 34 & 81,65 \\
Control & Posttest & & 52,50 \\
\hline
\end{tabular}

\section{Test for N-Gain HOTS and SL}

Based on the results of the HOTS NGain test, it shows an increase in both students who learn with inquiry-discovery and conventional learning. Firstly, the results of the HOTS N-Gain average test in the experimental class were 30 , the standard deviation was 2.63 , while in the control class the $\mathrm{N}$-Gain mean test results were 27 , and the standard deviation was 2.50. These results indicate students who learn with inquiry-discovery learning are higher than students who learn with conventional learning from both the mean and standard deviation. Secondly, the result of the $\mathrm{N}$-Gain SL test in the experimental class is 27 , the standard deviation is 2.62, while in the control class the $\mathrm{N}$-Gain average test results are 21, and the standard deviation is 2.28. These results indicate students who learn with inquiry-discovery learning are higher than students who learn with conventional learning both viewed from the average and standard deviation.
Normality Test Results for HOTS and SL

The results of the normality test based on the One-Sample Kolmogorov-Smirnov Test statistic showed that the results of pretest SL students in the experimental class using inquiry-discovery learning had Sig $>\alpha(0.574>0.05)$, and the posttest had Sig $>\alpha(0.454>0.05)$. In the same way, the results of the pretest of high-order thinking skills of students in the control class using conventional learning have Sig $>\alpha(0.726>0.05)$ and the posttest has Sig $>\alpha(0.318>0.05)$. Therefore, it can be concluded that the value of students' high-order thinking skills is normally distributed. The results of the normality test of scientific literacy values based on the One-Sample Kolmogorov-Smirnov Test statistic showed that the results of pretest scientific literacy using inquirydiscovery learning had Sig $>\alpha$ (0.653> $0.05)$, and the posttest had Sig $>\alpha(0.827>$ $0.05)$. Similarly, the results of the pretest of scientific literacy using conventional learning have $\mathrm{Sig}>\alpha(0.496>0.05)$ and posttest has Sig $>\alpha$ (0.536> 0.05$)$. Therefore, it can be concluded that the value of scientific literacy based on learning that is used is normally distributed.

\section{Homogeneity Test Results for HOTS and $S L$ values}

The result of homogeneity test using the Test of Homogeneity of Variances shows that the results of the homogeneity test of high-order thinking skills using inquiry-discovery learning have $\operatorname{Sig}>\alpha$ $(0.525>0.05)$ and the results of the homogeneity test of high-order thinking skills using conventional learning have Sig $>\alpha(0.739>0.05)$. Therefore, it can be concluded that the value of high-order thinking skills comes from a homogeneous group. Similarly, the results of the homogeneity test using the Test of Homogeneity of Variances showed that the results of the scientific literacy homogeneity test using inquiry-discovery 
learning had Sig $>\alpha(0.387>0.05)$ and the results of the test of scientific literacy homogeneity using conventional learning had Sig $>\alpha(0.723>0,05)$. Therefore, it can be concluded that the value of scientific literacy comes from a homogeneous group.

\section{HYPOTHESIS TESTING \\ Hypothesis 1 Test Results}

Based on the results of ANOVA analysis of two lanes of high-order thinking skills shows that Sig $>\alpha(0,000$ $<0,05)$, then $\mathrm{H}_{0}$ is rejected and $\mathrm{H}_{1}$ is accepted so that it can be concluded that students' high-order thinking skills taught with inquiry-discovery learning are higher than students who taught with conventional learning.

\section{Hypothesis 2 Test Results}

Based on the results of the two-way ANOVA analysis of the interaction between inquiry-discovery learning towards high-order thinking skills in terms of the students' initial ability shows that $\mathrm{Sig}>\alpha(0.737<0.05)$. Therefore, it can be concluded that $\mathrm{H}_{0}$ is accepted and $\mathrm{H}_{1}$ is rejected, this indicates that it is not there is an interaction between inquirydiscovery learning and higher-order thinking skills in terms of initial abilities.

\section{Hypothesis 3 Test Results}

Based on the results of two-way ANOVA analysis with Tukey's further test, high-order thinking skills of students with inquiry-discovery learning and conventional based on high initial ability shows that $\operatorname{Sig}<\alpha \quad(0.012<0.05)$. Therefore, it can be concluded that the students' higher order thinking skills with initial abilities height taught by inquirydiscovery learning is higher than students taught with conventional learning.

\section{Hypothesis 4 Test Results}

Based on the results of one-way ANOVA analysis with Tukey's advanced test students' high-order thinking skills with inquiry-discovery learning and conventional based on low initial ability shows that $\mathrm{Sig}<\alpha(0.003<0.05) . \mathrm{H}_{0}$ is rejected, and $\mathrm{H}_{1}$ is accepted so that it can be concluded that the students' high-order thinking skills with low initial abilities who are taught with inquiry-discovery learning are higher than students taught with conventional learning.

\section{Hypothesis 5 Test Results}

Based on the results of ANOVA analysis of two scientific literacy pathways shows that $\mathrm{Sig}>\alpha \quad(0,000$ $<0,05)$, then $\mathrm{H}_{0}$ is rejected and $\mathrm{H}_{1}$ is accepted so it can be concluded that students' scientific literacy taught by inquiry discovery is higher than students taught with conventional learning.

\section{Hypothesis 6 Test Results}

Based on the results of the Two-Way ANOVA analysis, interaction between inquiry-discovery learning to scientific literacy in terms of the students' initial abilities showed that Sig $<\alpha \quad(0.002$ $<0.05)$. Therefore, it can be concluded that $\mathrm{H}_{0}$ is rejected and $\mathrm{H}_{1}$ is accepted, this indicates that there is an interaction between inquiry-discovery learning of scientific literacy in terms of initial abilities.

\section{Hypothesis 7 Test Results}

Based on the results of one-way ANOVA analysis with Tukey's posthoc test, students' 'scientific literacy with inquiry-discovery learning and conventional based on high initial ability shows that $\mathrm{Sig}<\alpha(0,000<0,05), \mathrm{H}_{0}$ is rejected and $\mathrm{H}_{1}$ is accepted. Therefore, it can be concluded that students' scientific literacy with high initial abilities taught with inquiry-discovery learning is higher than students taught with conventional learning.

\section{Hypothesis 8 Test Results}

Based on the results of one-way ANOVA analysis with Tukey's posthoc test, students' 'scientific literacy with inquiry-discovery learning and conventional based on low initial ability shows that $\mathrm{Sig}<\alpha(0,000<0,05), \mathrm{H}_{0}$ is rejected and $\mathrm{H}_{1}$ is accepted. Therefore, it 
can be concluded that students' scientific literacy with low initial ability taught by inquiry discovery is higher than students taught with conventional learning.

Based on the results of statistical test data analysis, it shows that students who are taught with inquiry-discovery learning reached higher achievement than students taught with conventional learning do. This is evidenced by the results of the analysis that is Sig $<\alpha$ and is supported by mean values and $\mathrm{N}$-Gain higher-order thinking skills taught using inquiry-discovery learning is higher than the value of higher-order thinking skills taught using conventional learning. This is because inquiry-discovery learning models are more likely to facilitate students in highorder thinking. This can be seen clearly in the 6 stages of inquiry-discovery shown in Table 4 when compared to conventional learning which relies more on teachers as a source of knowledge information.

Inquiry-discovery learning gives students' direct experience, strengthens memory, and adds confidence in a concept with the process of finding itself. This is based on the results of interviews with some students who use inquirydiscovery learning. They stated that they experience an increase in the value of higher-order thinking because they do the practicum in the learning process and the learning video that enhances their memory of application of material or concept that the teacher who only told the application of the material. In addition, the practicum encouraged the development of student HOTS (Costa, 1985). The results of other studies stated that students who were taught with inquiry-discovery learning reached higher achievement than students taught with conventional learning (Wartono Wartono et al., 2018).

The results of the study also prove that there is no interaction between learning used and the students' initial ability to HOTS. Inquiry-discovery learning with initial abilities and conventional learning with initial ability does not influence each other on HOTS in matter pressure. This is in accordance with the reality on the ground when conducting research, in which students who have a high initial ability are very enthusiastic during the learning process. Students with high initial ability have more curiosity compared to other students. Furthermore, some students with low initial ability state that they do not like science lessons and some say they do not like science lessons, especially physics.

The results of the statistical test data analysis show that HOTS students with high initial ability who are taught with inquiry-discovery learning are higher than students taught with conventional learning. Based on the results of interviews with several students with high initial abilities who used inquirydiscovery learning, they got good grades because they had carried out the practicum on the material being tested and watched the video of material application and had done a lot of exercises during the learning process.

The results of statistical test data analysis also showed that HOTS students with low initial ability who were taught with inquiry discovery were higher than students taught with conventional learning. Based on the results of interviews with some students with low initial abilities who used inquirydiscovery learning, they got better grades from the pre-test because they had carried out the practicum and watched the video of material application and the exercises were sufficient, even though they still have not achieved minimal mastery in the posttest scores. The results of interviews with low initial ability students also said that they did not like science lessons.

Thus, HOTS with high discoveryinquiry learning groups will achieve the highest achievement and low groups will 
achieve lower achievement than high initial ability students will. Based on the results of his research also shows that students with high and low initial abilities have an increase (Madhuri et al., 2012).

The results of the study prove that inquiry-discovery learning and conventional learning affect scientific literacy. This is supported by the results of research showing that SL students who are taught with inquiry discovery are higher than students taught with conventional learning. The results of this study in accordance with the research (Fatmawati, I.N \& Utari, 2015) show that the application of levels of inquiry can improve the scientific literacy of junior high school students.

The success of inquiry-discovery learning is due to being able to train students to find concepts and facts about scientific phenomena with the potential of students so that they are able to understand the concepts learned through direct experience (Belton, 2016) and can improve students' learning outcomes.

Table 4. Inquiry-discovery learning stages Eggen \& Kauchak (1996)

\begin{tabular}{|c|c|c|}
\hline Phase & Teacher Activities & Students Activities \\
\hline $\begin{array}{l}\text { Presenting questions or } \\
\text { problems }\end{array}$ & $\begin{array}{l}\text { - Provide a stimulus in the form } \\
\text { of a problem in students } \\
\text { - Guiding students to identify } \\
\text { problems } \\
\text { - Divide students into groups }\end{array}$ & 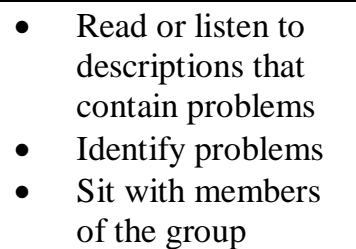 \\
\hline Make a hypothesis & 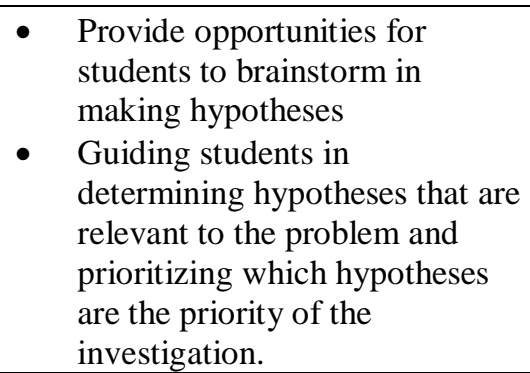 & $\begin{array}{l}\text { Make hypotheses } \\
\text { as temporary } \\
\text { answers to } \\
\text { problems that have } \\
\text { been formulated by } \\
\text { themselves }\end{array}$ \\
\hline Design an experiment & $\begin{array}{l}\text { Provide opportunities for } \\
\text { students to determine the steps } \\
\text { that are in accordance with the } \\
\text { hypothesis that will be done. } \\
\text { Guiding students to sort out } \\
\text { problem-solving steps. }\end{array}$ & $\begin{array}{l}\text { Discuss in } \\
\text { determining and } \\
\text { sorting the steps in } \\
\text { the experiment }\end{array}$ \\
\hline $\begin{array}{l}\text { Conduct an experiment to } \\
\text { obtain information }\end{array}$ & $\begin{array}{l}\text { - Guiding students to get other } \\
\text { information through } \\
\text { experiments } \\
\text { - Guiding students in carrying } \\
\text { out experiments }\end{array}$ & $\begin{array}{l}\text { - Discuss in finding } \\
\text { new information or } \\
\text { knowledge through } \\
\text { experiments }\end{array}$ \\
\hline Collect and analyze data & $\begin{array}{l}\text { Guiding students in collecting } \\
\text { and processing data from } \\
\text { experimental results } \\
\text { Provide opportunities for each } \\
\text { group to convey the results of } \\
\text { the data collected } \\
\text { Give reinforcement and direct } \\
\text { students to check/examine } \\
\text { hypotheses made by students at } \\
\text { the beginning of the activity } \\
\text { whether the hypothesis is } \\
\text { proven or not }\end{array}$ & 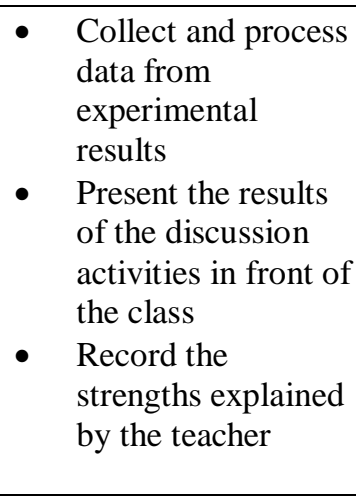 \\
\hline
\end{tabular}


The results of the study also prove that there is an interaction between learning used and the students' initial ability to scientific literacy. Inquirydiscovery learning with initial abilities and conventional learning with initial abilities will interact with scientific literacy in substance pressure material.

Learning is an external thing that can affect the ability of students SL. In addition to external factors, the internal is also very influential with everything that is in the students that support learning such as intelligence, talent, five sensory motor skills, and thinking schemes. Students' intelligence such as students' initial ability to physics is certainly influential because there has been a study before the experiment was conducted (Risqiana, N., Hidayat, A., Soepriyono, 2015).

Table 5. Students' Answers to HOTS and SL Aspects

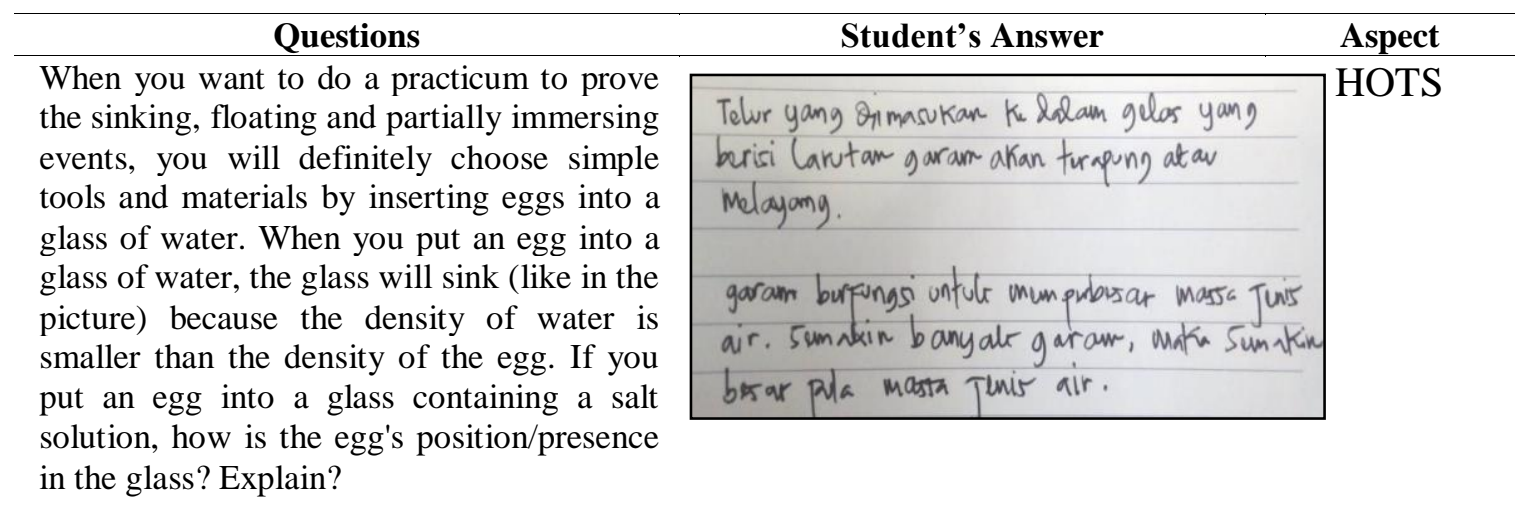

Aldo is doing a practicum about Archimedes' law. The practicum was carried out to prove the sinking, floating and partially immersing event. He observed this by inserting eggs into water containing a salt solution. Tools and ingredients that must be prepared are glass (3 pieces), eggs (3 grains), spoons, and salt. The steps he did were the three glasses filled with a little water. Glass 1 contains water without a mixture of salt, glass 2 contains water and salt as much as one spoon then stir until

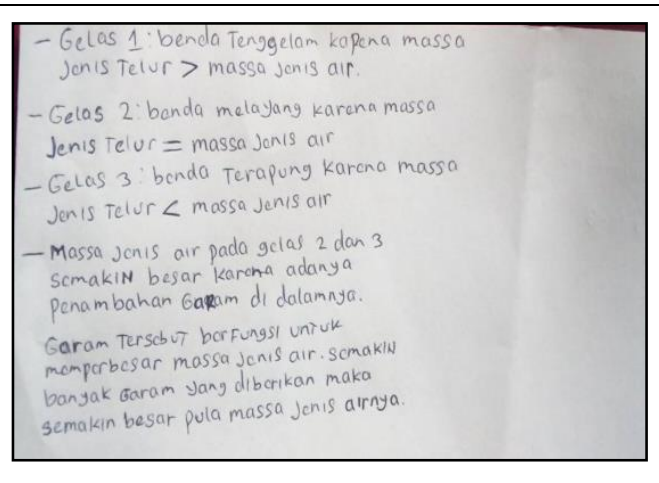

SL evenly distributed, while glass 3 contains water and salt as much as three spoons then stirred until evenly distributed. The final step he did was to insert the egg into three glasses, and then he observed the existence of the egg. The presence of eggs in glass 1 sinks, glass 2 floats, and glass 3 floats.

The results of the statistical test data analysis show that SL students with high initial ability who are taught with inquirydiscovery learning are higher than students taught with conventional learning. Based on the results of interviews with several students with high initial abilities who learned to use inquirydiscovery learning, they got good grades because they had carried out the practicum on the material being tested and watched the video of material application and did a lot of exercises during the learning process, which is in the form of 
literacy. Therefore, it helps them to get used to working on literacy questions. The results of interviews with students with high initial abilities also said that they had the intention to learn on their own and had more curiosity; this was seen during the learning process.

The results of statistical test data analysis also showed that the scientific literacy of students with low initial ability who were taught with inquiry-discovery learning was higher than students taught with conventional learning. Based on the results of interviews with some students with low initial abilities who learned to use inquiry-discovery learning said that they got better grades from the pre-test because they had carried out the practicum and watched the video of material application learned and enough exercises, even though they still have not achieved minimal mastery in the posttest scores. The results of interviews with students with low initial abilities also said that they did not like science lessons, especially physics.

The results of this study are similar to research (Mawardini, Permanasari, \& Sanjaya, 2015), which shows that the achievement of the average scientific literacy of high group students is better than the students in the medium and low groups, and the students in the medium group are better than the low group students. Inquiry-discovery learning invites students to search for concepts by practicing and emphasizes learning through experience (Tompo et al., 2016).

The success of inquiry-discovery learning occurs because the direct role of students in exploring the material through the practicum with directed steps in this learning and can make students more independent and responsible. This is consistent with the advantages of inquirydiscovery learning that is studentcentered, and knowledge will last longer or be easier to remember (Vlassi \& Karaliota, 2013). Based on this, this learning can help students obtain good learning outcomes because the knowledge or knowledge they gain can last a long time and is easy to remember.

\section{CONCLUSIONS AND SUGGESTIONS}

Based on the results of data analysis and discussion, it can be concluded that the high-order thinking skills of students taught with inquiry-discovery learning are higher than students taught with conventional learning. There is no interaction between inquiry-discovery learning and higher-order thinking skills in terms of initial abilities. Higher-order thinking skills of high initial abilities students who were taught by inquirydiscovery learning are higher than students taught with conventional learning. Higher-order thinking skills of low initial abilities students taught by inquiry-discovery learning are higher than students taught by conventional learning. Scientific literacy of students who were taught with inquiry-discovery learning is higher than students taught with conventional learning.

There is an interaction between inquiry-discovery learning to scientific literacy in terms of initial abilities of students' scientific literacy with high initial abilities that were taught with inquiry-discovery learning. They achieved higher than students taught with conventional learning. Furthermore, scientific literacy students with low initial abilities who are taught with inquirydiscovery learning are higher than students taught with conventional learning.

Thus, inquiry-discovery learning models can be recommended in increasing HOTS and SL students. Teachers are expected to measure other activities of students in improving learning and learning outcomes of students' physics. 


\section{REFERENCES}

Batlolona, J. R., \& Haumahu. (2016). Aktivitas Siswa Dalam Pembelajaran Fisika Pada Konsep Listrik Dinamis Dengan Menerapkan Media Interaktif Siswa Kelas $X$ SMA Kristen YPKPM Ambon [Student Activity in Learning Physics on the Concept of Dynamic Electricity by Applying Interactive Media to Cla. Seminar Nasional Pekan Ilmiah Fisika (PIF) XXVII, 88-91.

Belton, D. J. (2016). Teaching process simulation using video-enhanced and discovery/inquiry-based learning: Methodology and analysis within a theoretical framework for skill acquisition. Education for Chemical Engineers, 17(2002), 54-64. https://doi.org/10.1016/j.ece.2016.08 .003

Bloom, B. S. (1956). Taxonomy of educational objectives, Handbook I: The cognitive domain. New York: McKay.

Bruner, J. S. (1961). The act of discovery. Harvard Educational Review, 31, 21-32.

Çepni, S., Ayvacı, H. Ş., \& Bacanak, A. T.-K. M. (2004). Fen Eğitimine Yeni Bir Bakıs, Fen Teknoloji-Toplum. Trabzon: Top-Kar Matbaacilik.

Clark, D. (2010). Bloom's taxonomy of learning domains: The three types of learning. Big Dog \& Little Dog's Performance Juxtaposition.

Costa, A. L. (1985). Developing Minds : A Resource Book for Teaching Thinking. West Street Alexandria, Virginia: ASCD.

Dillon, J., \& Scott, W. (2002). Editorial perspectives on environmental education-related research in science education. International Journal of Science Education, 24(11), 11111117.

https://doi.org/10.1080/09500690210 137737

Fatmawati, I.N \& Utari, S. (2015).
Penerapan Levels of Inquiry untuk Meningkatkan Literasi Sains Siswa SMP Tema Limbah dan Upaya Penanggulangannya. Jurnal Edusains, 7(2), 152-159.

Firman, H. (2007). Analisis Literasi Sains Berdasarkan Hasil PISA Nasional Tahun 2006. Jakarta: Pusat Penelitian Pendidikan Balitbang Depdiknas.

Fives, H., Huebner, W., Birnbaum, A. S., \& Nicolich, M. (2014). Developing a Measure of Scientific Literacy for Middle School Students. Science Education, 98(4), 549-580. https://doi.org/10.1002/sce.21115

Forehand, $\mathrm{M}$. (2011). BloomsTaxonomy.pdf. Bloom's Taxanomy-Emerging Perspective on Learning, Teaching and Technology, p. 10. https://doi.org/10.4135/97814129574 03.n51

Gormally, C., Brickman, P., \& Lut, M. (2012). Developing a test of scientific literacy skills (TOSLS): Measuring undergraduates' evaluation of scientific information and arguments. CBE Life Sciences Education, 11(4), 364-377. https://doi.org/10.1187/cbe.12-030026

In'am, Akhsanul; Hajar, S. (2017). Approach. 10(1), 55-70.

Jonassen, D. H. (1991). Objectivism vs.constructivism: Do we need a new philosophical paradigm? Educational Technology: Research and Development, 39(3), 5-14.

Klahr, D., \& Nigam, M. (2004). The equivalence of learning paths in early science instruction: Effects of direct instruction and discovery learning. Psychological Science, 15(10), 661-667. https://doi.org/10.1111/j.09567976.2004.00737.x

Loverude, M. E., Kautz, C. H., \& Heron, P. R. L. (2003). Helping students 
develop an understanding of Archimedes' principle. I. Research on student understanding. American Journal of Physics, 71(11), 11781187.

https://doi.org/10.1119/1.1607335

Madhuri, V. G., Kantamreddi, S. V, \& Prakash Goteti, N. L. (2012). Promoting Higher Order Thinking Skills Using Inquiry-Based Learning. European Journal of Engineering Education, 37(April 2013), 117-123. https://doi.org/10.1080/03043797.20 12.661701

Mawardini, A., Permanasari, A., \& Sanjaya, Y. (2015). Profil Literasi Sains Siswa Smp Pada Pembelajaran Ipa Terpadu Tema Pencemaran Lingkungan Snf2015-Iv-49 Snf2015Iv-50. IV(1996), 49-56.

Meijerman, I., Storm, G., Moret, E., \& Koster, A. (2013). Development and student evaluation of an inquirybased elective course on drug discovery and preclinical drug development. Currents in Pharmacy Teaching and Learning, 5(1), 14-22. https://doi.org/10.1016/j.cptl.2012.09 .009

Miri, B., David, B. C., \& Uri, Z. (2007). Purposely teaching for the promotion of higher-order thinking skills: A case of critical thinking. Research in Science Education, 37(4), 353-369. https://doi.org/10.1007/s11165-0069029-2

OECD. (2001). OECD Annual Report 2001. In publié en français sous le titre. Paris, France.

OECD. (2004). OECD Annual Report 2004. In publié en français sous le titre. Retrieved from https://www.oecd.org/corporate/ca/c orporategovernanceprinciples/31557 724.pdf

OECD. (2006). OECD Annual Report 2006. https://doi.org/10.1787/annrep2006-en

OECD. (2009). OECD Annual report
2009. Paris, France: publié en français sous le titre.

OECD. (2014). OECD Annual Report 2014.

https://doi.org/10.1787/eag_highlight s-2014-en

PISA 2006 P rogramme for I nternational $S$ tudent A ssessment. (2006).

Piten, S., Rakkapao, S., \& Prasitpong, S. (2017). Cambodian students' prior knowledge of projectile motion. Journal of Physics: Conference Series, 901(1). https://doi.org/10.1088/17426596/901/1/012116

Polly, D., Ausband, L., Polly, D., \& Ausband, L. (2014). Skills through WebOuests. (January 2015), 37-41. https://doi.org/10.1080/10402454.20 09.10784628

Putri, Z. A. (2018). Rata-rata Nilai UN SMP 2018 alami penurunan.

Richardson, V., \& Renner, J. W. (1970). A Study of the Inquiry-Discovery Method of Laboratory instruction. $J$. Chem. Educ., 47(1), 77-79. https://doi.org/10.1021/ed047p77

Risqiana, N., Hidayat, A., Soepriyono, K. H. (2015). Pengaruh Pembelajaran Fisika Model Problem Based Learning (PBL) terhadap Kemampuan Literasi Sains Siswa Ditinjau dari Kemampuan Awal [The Effect of Physics Learning on Problem Based Learning Model (PBL) on Students' Science Literacy Ability Viewed from In. Prosiding Pertemuan Ilmiah. Malang: Universitas Kanjuruhan Malang.

Saab, N., Van Joolingen, W. R., \& Van Hout-Wolters, B. H. A. M. (2005). Communication in collaborative discovery learning. British Journal of Educational Psychology, 75(4), 603-621.

https://doi.org/10.1348/000709905X 42905

Sund, R. B., \& Trowbridge, L. W. (1973). Teaching science by inquiry in the 
secondary school. Merrill Publishing Company.

Susman, K., \& Pavlin, J. (n.d.). It Seems Easy To Float, But Is It Really? a. $1-11$.

Taale, K. D. (2011). Improving physics problem solving skills of students of Somanya Senior High Secondary Technical School in the Yilo Krobo District of Eastern Region of Ghana. Journal of Education and Practice, 2(6), 8-21.

Tompo, B., Ahmad, A., \& Muris, M. (2016). The development of discovery-inquiry learning model to reduce the science misconceptions of junior high school students. International Journal of Environmental and Science Education, 11(12), 5676-5686.

Turgut, H. (2007). Scientific Literacy for All. Ankara University, Journal of Faculty of Educational Sciences, 40(2), 233-256. https://doi.org/10.1501/Egifak_0000 000176

Vlassi, M., \& Karaliota, A. (2013). The Comparison between Guided Inquiry and Traditional Teaching Method. A Case Study for the Teaching of the Structure of Matter to 8th Grade Greek Students. Procedia - Social and Behavioral Sciences, 93, 494497.

https://doi.org/10.1016/j.sbspro.2013 .09 .226

Wartono, W., Diantoro, M., \& Bartlolona, J. R. (2018). Influence of Problem Based Learning Learning Model on Student Creative Thinking on Elasticity Topics A Material. Jurnal Pendidikan Fisika Indonesia, 14(1), 32-39.

https://doi.org/10.15294/jpfi.v14i1.1 0654

Wartono, W., Hudha, M. N., \& Batlolona, J. R. (2018). How are the physics critical thinking skills of the students taught by using inquiry-discovery through empirical and theorethical overview? Eurasia Journal of Mathematics, Science and Technology Education, 14(2), 691697.

https://doi.org/10.12973/ejmste/8063 2

Wilks, S. (1995). Critical \& creative thinking: Strategies for classroom inquiry. Heinemann Educational Publishers.

Yahya, A. A., Toukal, Z., \& Osman, A. (2012). Bloom 's Taxonomy Based Classification for Item Bank. Modern Advances in Intelligent Systems and Tools, 431, 135-140.

Yuenyong, C. (2013). Enhancing Scientific Literacy in Thailand. Global Studies of Childhood, 3(1).

Zohar, A. (2004). Higher order thinking in science classrooms: Students' learning and teachers' professional development (Vol. 22). Springer Science \& Business Media.

Zoller, U., Dori, Y. J., \& Lubezky, A. (2002). Algorithmic, LOCS and HOCS (chemistry) exam questions: Performance and attitudes of college students. International Journal of Science Education, 24(2), 185-203. https://doi.org/10.1080/09500690110 049060 